\title{
Adaptation of labour migrants as a function of social management
}

\begin{abstract}
The twentieth century has already been named an era of migration; Russia has not avoided this trend and, moreover, has faced an enormous flow of immigrants. The new social situation deriving out of this situation calls for adaptation to take place in the framework of the formal and informal institutions of the host society. The goal of social management is to optimise the existing system of institutions; this article is an attempt to cover several directions of adaptation from the perspective of the new institutional approach and social management.
\end{abstract}

Keywords: labour immigration, adaptation, institution

\section{Introduction}

The collapse of the USSR became the turning point of the process of the 'opening' of the borders of Russia together with the other countries in the Commonwealth of Independent States (CIS). This process took place within the broader framework of globalisation and, speaking more locally, that of European integration. Migration has become an integral part of the contemporary world economy; most of all, the migration of the labour force - labour migration. This has resulted in the appearance of interdependence between countries sending and receiving migrants.

Russia is not a traditional immigrant-receiving nation (like Canada, the USA, Australia, New Zealand) but it is now trying on this new role: according to the statistics of the World Bank, Russia stands in second place in the world among countries receiving immigrants after the United States of America. ${ }^{1}$ The Russian Federation is the main point of attraction for immigrants in the CIS region. According to the basic economic law of demand and supply, migrants from neighbouring countries are able to find jobs in the labour market of Russia, which features an imbalance resulting from a lack of an unqualified or low-skilled workforce. It is labour migrants from CIS countries coming in on a visa-free regime that constitutes the majority of the immigrant flow to Russia (including, but not limited to, Tajikistan, Uzbekistan, Kirgizia, Ukraine, Moldova).

Taking the position of a receiving country accordingly leads to experiencing the positive and negative effects of labour immigration, which Russia faces like other host countries:

1 'Russia Second-Largest Migrant-Receiving Country In World, Says World Bank Report' http:// web.worldbank.org/WBSITE/EXTERNAL/TOPICS/EXTPOVERTY/EXTMIGDEV/0,,contentMDK:21183758 pagePK:210058 piPK:210062 theSitePK:2838223,00.html [last accessed 15 April 2010]. 
- the economic effects include that the costs of the labour force, and consequently costs in general, go down

- migrants are consumers of commodities and services on the market of the host country, which means that the market grows

- labour immigrants might contribute to opportunities for the vertical mobility of the 'local' workforce occupying unpopular workplaces

- in the case of legal employment, the state budget receives tax proceeds

- the demographic structure can benefit from it

- labour migration can be a way of recruiting a highly qualified and/or rare workforce.

On the other hand, effects of another kind cannot be overlooked:

- this can lead to a deterioration in the situation of local labour markets

- an uneven distribution of labour immigrants on the territory of the host country, i.e. their concentration in the most developed regions and the big cities

- possibilities of social tension and the promotion of discriminatory practices

- risks of the marginalisation of labour immigrants resulting from the adaptation process proceeding in a direction undesirable for both immigrants and, in the end, the host society.

Successful adaptation can be a factor contributing to the elimination of marginalisation. The goal of social management, therefore, is the promotion of adaptation in this direction, as opposed to marginalisation.

Adaptation is understood as a process of the mutual adjustment both of newcomers and of the receiving society, resulting in the appearance of new social patterns. In accordance with this new institutional approach, adaptation takes place within the framework of the host society and is influenced by its institutions (both formally and informally). The adjustment processes are regulated by the institutions, i.e. the rules of the routine interactions and the mechanisms for their maintenance ${ }^{2}$ at the same time, the institutions are created and transformed by individuals. Thus, more specifically, the goal of social management can be put as follows: to guarantee the effectiveness of the institutions for successful adaptation.

\section{Material and methods}

For this research study, the following hypothesis was set up: formal and informal institutions might not be favourable to the adaptation of labour immigrants in St. Petersburg.

Formal institutions do not exist in all spheres; instead, informal ones appear. Moreover, informal structures might exist even as alternatives to formal ones, i.e. in parallel. However, such informal institutions might be connected with illegal practices and thus contribute to marginalisation and adaptation in this direction, which would be negative for both sides.

2 North, D (1990) Institutions, Institutional Change and Economic Performance Cambridge University Press. 
The hypothesis was examined in the case of a construction company in St. Petersburg, which is a popular destination for immigrants.

Migration can serve as a reliable indicator of the level of differentiation in the socioeconomic development of regions, ${ }^{3}$ and it can be proved as regards the distribution of labour immigrants in Russia: the most popular regions are those which are economically the most developed: Moscow region; Hanty-Mansiysky and Yamalo-Nenecky autonomous districts; Sverdlovsk region; Primorsky kray; and St. Petersburg. ${ }^{4}$

The majority of labour immigrants in Russia are employed in the construction sector (43\%). ${ }^{5}$ However, some difficulties were apparent when searching for a construction company which was prepared to let in a researcher due to the practice of illegal employment: letting an outsider in means the risk of some information coming out. The situation was worsened as a result of the economic crisis: two companies rejected participation, explaining it by saying that all topics connected with labour immigrants were banned as they had not paid them salaries for three months already. It is worth mentioning that participation was rejected despite assurances of anonymity and despite all the research taking place through social networks which could serve as an additional guarantee.

Finally, however, a construction company was found. It is estimated by its head and co-owner as a 'middle-sized company' in St. Petersburg: 'neither big nor small'. It has now been operating on the market for the last eight years. It serves as a subcontractor on several sites both in St. Petersburg and in the suburbs, mainly in finishing work but also in construction itself. I carried out semi-formal interviews with the head of the company, as well as with the site supervisor and some workers on a construction site (both from St. Petersburg and from CIS countries, namely Ukraine, Kirgizia and Tajikistan). During the interviews, I covered different aspects of adaptation, namely: obtaining information about labour migration to Russia (the rights and requirements determined under the laws of the Russian Federation, opportunities for and different spheres of employment; etc); the resolution of legal matters (migration registration, work permits); sorting out the questions connected with employment (looking for a job, agreement with an employer either orally or in written form, etc); and developing social relationships. I should mention that all the migrants had come for a period of time to work and to earn money (usually for some purpose: marriage; house construction; etc). Their families are in their native countries and this creates an interesting position of theirs, occupying a place in the middle between their country of work and their country of origin. They work in Russia for a period of about one year (the length of a work permit) then return 'on vacation', before coming back again. Their whole life course and life planning is special.

3 Зайончковская Ж (1998) ‘Рынок труда как регулятор миграционных потоков’ Миграция $u$ рынки труда в постсоветской России// Под ред. Г. Витковской. М, р. 27.

4 Труд и занятость в России - 20072. сайт Федеральной службы государственной статистики: http://www.gks.ru/bgd/reg1/B07_36/IssWWW.exe/Stg/d01/05-18.htm [last accessed 15 April 2010].

5 'Are You Happy to Cheat Us?' The Exploitation of Migrant Construction Workers in Russia Human Rights Watch Report http://www.hrw.org/en/reports/2009/02/09/are-you-happy-cheatus-0 [last accessed 15 April 2010]. 
The research also required an analysis of the laws of the Russian Federation which are devoted to the question of labour immigration from CIS countries (which does not require a visa), as well as some basic international norms (conventions) and the bilateral and multilateral agreements which exist between Russia and the countries which are exporters of labour.

\section{Theoretical basis of research into adaptation}

In general, adaptation can be understood as a two-sided process: the first part is 'fitting in' to the society in which settlement takes place and functioning successfully in the new environment; the second is acceptance by the host society. The outcome is the appearance of new social patterns.

There are at least two main sociological perspectives which can be mentioned when speaking of adaptation. The first, which can be called normative (E. Durkheim, T. Parsons, R. Merton), presupposes that there are some supra-individual substances existing in society - social facts - which have a compulsory character:

They consist of manners of acting, thinking and feeling external to the individual, which are invested with a coercive power by virtue of which they exercise control over him. ${ }^{6}$

Adaptation is seen as a process directed by them and, in its course, a person learns all the necessary patterns, norms and values and thus enters the social system. A person learns the cultural patterns and, while his/her opportunities of influence remain limited, innovative change can only take place on the side (whether constructive or disruptive). Thanks to this, the structure of social action obtains structural supports which are both high and stable. ${ }^{7}$ Stability, equilibrium and balance between the needs and interests of an individual and the social environment serve as the goals of the adaptation process; with a view to ensure that social control is functioning, it checks the level of accordance with the dominant values and thus the whole system is oriented towards the normative order.

Robert Merton enriched this approach by paying attention not only to the goals defined by culture but also to the opportunities for their realisation. Moreover, he declared that the normative structure of society, which calls for adaptation every time a person takes up a new role in a specific situation, was essentially conflictual. Merton created a typology of modes of adaptation: conformity; innovation; ritualism; retreatism; rebellion - each of which is defined in two dimensions: the extent of acceptance/rejection of the goal; and the ease of access to the means of its realisation. ${ }^{8}$

In the framework of the second - interpretative - approach (A. Schutz, P. Berger, T. Lukman), a person obtains a more active role in adaptation. In the course of everyday interactions within his/her 'native' society, he/she uses the schemes and patterns which

6 Durkheim, E (1982) The Rules of the Sociological Method New York: Free Press, pp. 50-59.

7 Parsons, E (1966) Societies: Evolutionary and Comparative Perspectives Englewood Cliffs, NJ: Prentice-Hall.

8 Мертон, Р (1966) 'Социальная структура и аномия' Социология преступности (Современные буржуазные теории) М, pp. 299-313. 
are 'set by default' and which do not require any additional explanation. Fundamental to this approach is Weber's sociology, whose primary focus is on the subjective meanings that actors attach to their actions in their mutual orientations. Therefore, a person always directs his/her actions in accordance with the generalised 'other' (the G. H. Mead concept); he/she must permanently interpret social reality, which calls for the continual modification of behaviour and its adjustment - even more so, if we recall the situation of an alien. When an alien gets in touch with a host group, he/she faces the problem of interpreting the actions of others, as he/she does not know all the patterns required for correct interpretation and, thus, the adequate action in response. Thus, the adaptation of an alien means a process of getting to know the patterns used in the host society in the process of interaction, in the result of which there appears shared knowledge. Social control in its various forms can enable some patterns of constructs after they turn into standards of behaviour. ${ }^{9}$

Classical theories of assimilation (Park, Burgess, Gordon) can be seen as related to the second, interpretative approach. They presuppose that the final result of adaptation is inevitable assimilation, i.e. the substitution of the norms, values, etc. of the 'old' society with those of the new. Assimilation is understood as the final stage of adaptation: contact; competition; conflict; accommodation; assimilation. ${ }^{10}$ Therefore, at the last stage (which can be reached by a second generation), a migrant group is melded into the receiving community.

However, this assimilationist approach has narrowed the research perspective and, lately, the possibility of the successful functioning of a single 'melting pot' has been questioned; despite the recent advocates of this approach, ${ }^{11}$ social sciences recently tend to acknowledge a plurality of the results of adaptation, instead of there being a single result (assimilation), and that this plurality depends on multiple factors. ${ }^{12}$

The neo-institutional approach offers another interesting perspective in the sense that, even though its main thesis is that 'institutions matter', it nonetheless pays attention to the actor as well. Moreover, it differs from normative theories in its view of a person as an active individual. Institutions shape routine interactions, but they can be created and transformed by individuals.

9 Щюц, А (2004) Мир, светящийся смыслом. М, р. 21.

10 Park, R (1921) 'Human migration and the marginal man' American Journal of Sociology 33: 881-93; Park, R. and E. Burgess On Competition, Conflict, Accommodation and Acculturation http://media.pfeiffer.edu/lridener/courses/COMPCONF.HTML [last accessed 15 April 2010]; Park, R. and W. Thomas (1927) 'Participation and Social Assimilation' in Kimball Young (Ed.) Source Book For Social Psychology New York: A. A. Knopf), pp. 47-53 http:// www.brocku.ca/MeadProject/Thomas/Thomas_1927d.html [last accessed 15 April 2010].

11 Alba, R and V. Nee (1997) 'Rethinking assimilation theory for a new era of immigration' International Migration Review 31(4); Alba, R and V. Nee (2005) Remaking the American Mainstream: Assimilation and Contemporary Immigration Harvard University Press.

12 Schmitter, Heisler B (2008) 'The Sociology of Immigration' in Caroline B. Brettel and James F. Hollifield (Eds.) Migration Theory: Talking across disciplines Routledge, pp. 83-113. 
An institution can be defined as an:

Interrelated system of institutional elements - formal and informal - facilitating, motivating, a governing and economic action ${ }^{13}$

as well as encompassing mechanisms for their enabling and support. The distinction between 'formal' and 'informal' institutions is not a strict dichotomy but, rather, a continuum in which the indicators of formality are connected with written fixation and state enforcement: formal institutions are defined in the laws and usually created on purpose; informal institutions appear spontaneously. It is important to note that informal institutions are not bound to illegal practices; secondly, they might embrace not only some historically-derived norms and traditions but also some innovative strategies. $^{14}$

However, once appeared or having been created, an institution can continue without being effective - above all, in the sense of decreasing transaction costs. Institutions limit the set of alternatives available to the actor and, as such, they contribute to the elimination of uncertainty - and, consequently, to the elimination of the risks and costs of information and co-ordination. The effectiveness of an institution can be measured with the help of indicators connected with its significant transaction costs; but there are costs which are very difficult to calculate: for example, time spent on information search and in queues, bribes and the losses resulting from improper control and supervision. The maintenance of institutions means that they reproduce themselves, in which there are three factors involved:

- they allow society to function in its contemporary conditions (perhaps in the absence of purer forms of the market)

- institutions are internalised

- institutions are embedded in the inter-related system of institutions in such a way that it is hard to modify one without dealing with the others. ${ }^{15}$

Therefore, adaptation takes place in a context structured with institutions, each of which is associated with higher/lower transaction costs; in which institutions may be created and modified by actors, social groups, etc. However, it is not so easy to deconstruct an institution in the case of its ineffectiveness. At the same time, adaptation can be seen as a function of social management which, on the level of the whole society, is understood as a mechanism of internal self-regulation as well as the:

13 Nee, V (2003) 'The New Institutionalism in Economics and Sociology' CSES Working Paper Series No. 4 http://www.economyandsociety.org/publications/working_papers.shtml p. 63 [last accessed 15 April 2010].

14 Радаев, В (2001) Новый институичональный подход и деформализация правил российской экономики Препринт WP1/2001/01, Серия WP1 Институциональные проблемы российской экономики. М, p. 24.

15 Guilmoto, C and F. Sandron (2001) 'The Internal Dynamics of Migration Networks in Developing Countries' Population: An English Selection 13(2). 
Goal-oriented and value-oriented interaction of actors of management practices which guarantee satisfaction of needs and realization of interests of managed and managing parties with the help of reaching consensus and shared aims. ${ }^{16}$

\section{Research results}

Having analysed the laws of the Russian Federation devoted to the issue of visafree labour immigration from CIS countries, and conducted interviews, I can draw the following conclusions. Formal institutions do not exist in all the spheres listed above. However, these spaces are not staying empty and are being filled by informal institutions. Moreover, the latter can appear and act in parallel with formal institutions in cases where they are estimated by individuals as less costly. What is interesting is that informal institutions are being built into formal ones. The problem, however, is that the informal institutions are likely to be connected to illegal practices.

All information about migration is spread through the social networks of potential immigrants. At the moment, there are no effective formal institutions which cope with this task. In creating channels of information for potential immigrants, it is important to bear in mind that the majority of immigrants come from villages (kishlaki) which are not provided with the internet or simple computers; so, any attempts to upload necessary information (such as the requirements of contemporary Russian laws) on the websites of the Federal Migration Office deliver only a very small impact. Moreover, information there is displayed in two languages: Russian and English. This does not correspond with the needs of immigrants (some of them hardly speak Russian, let alone English). Recently, a test version of an information bank has been created within the framework of the bilateral agreement between Russia and Tajikistan, but it includes information concerned only with employment opportunities (available workplaces, employers, regions).

Coming to Russia requires preparation if a person is to see a reductions in the risks. Preparation implies a search among friends, relatives, fellow countrymen, etc. already working in Russia. In this situation, weak ties can help a lot: starting from initial accommodation, the obtaining of registration and work permits, to the job search.

Despite the immigration reforms of 2005-06, the requirements for obtaining work permits and registration are quite strict. A migrant is supposed to be registered during the three working days after arrival in the presence of some 'receiving party' (this can be an employer or a 'local' person). The amount of work permits that can be issued is assigned annually for every region but can be adjusted. Nevertheless, the mechanism for the calculation of quotas is not clear and serves as a source of instability and insecurity. Figures are gathered by local government from employers; all information is then stored at the centre and the Ministry of Health and Social Development, together with the Ministry of Economics and the Federal Migration Office, makes a decision on the final figure and its distribution between the regions, economic sectors and countries of origin.

Волчкова, Л. Т (2008) ‘Качество социального управления: междисциплинарный подход к исследованию’ Качество управления: междисииплинарный анализ. Материалы междисииплинарного семинара по управлению. Выпуск девятый. СПб, р. 11. 
However, this tool is not properly adjusted to the circumstances: employers do not have to declare their need for immigrants and, therefore, the figures are lower than the real needs at the country-wide level and the quotas come to an end earlier than at the end of the year. Employers, for their part, do not see the necessity of participating in this system: an employer can work with a labour immigrant regardless of whether he or she has addressed a request to the appropriate authorities. Sometimes, a conflicting situation might take place in which employers who have taken part in this system cannot employ any immigrants as quotas are over before they have satisfied their need for staff.

The second negative effect is the opportunity for personal influence on the calculation of quotas by some politicians: for instance, the statement in December 2008 of Prime Minister Vladimir Putin on the necessity to lower the quotas by $50 \% .{ }^{17}$ Ultimately, the quota was not cut so sharply, but such statements do contribute to the instability and uncertainty which might lead to further developments in the illegal obtaining of work permits.

In cases where a migrant is not able to carry out the necessary requirements to obtain all the documentation, he/she can be provided with the assistance of a mediator. The services of mediators can include the execution of all papers, organisation of transfers and job search. The operation of mediation institutions differs considerably: for instance, the documents which are provided to a 'client' may be legal, even where the means of doing so has been illegal. In this case, this is seen as an 'extra service' performed legally, but with some additional payment. It can be connected to illegal practices (a mediator can take money and cheat; a mediator can provide a person with fake documents).

Similarly, there is no developed labour market for the employer and the potential employee. A check of qualifications is carried out on the spot through the performance of test tasks. Furthermore, the price paid for following the formal rules of employment is higher for the employer than are the penalties for their breach. Thus, illegal employment is practised.

The search by employees for work is carried out with the help of social networks as well; in this search, one of the most important factors is that the employer is known as reliable, above all in terms of the payment of salaries. Reputation and trust, together with a circle of people who can work themselves as well as recommend others, are assets in the employee search. These means serve to decrease the risks.

Illegal employment is considered less costly, but there are no written agreements between employer and employee. Again, what plays an important role here is trust, which is often built on personal relationships not necessarily with the head of the company but with the site supervisor who serves as his or her deputy on a specific building site.

Even having all the necessary paperwork does not secure a migrant against bribes and it hampers their successful adaptation, even in the sense that it prevents him or her from familiarisation with the city space. Bribes become a universal means of resolving

17 See article: Премьер России предложил сократить квоту на привлечение мигрантов http://www.rg.ru/2008/12/04/kvota-anons.html [last accessed 15 April 2010]. 
problems: starting from questions of illegal employment with the police and the Federal Migration Office, to deals with the emergency services in cases of the injury or even death of a migrant, since construction is a dangerous sector.

The high risk of bribes when walking in the city, together with the hard physical work and the long working day and week, prevent migrants from broadening their social networks; of course, poor mastery of the Russian language and xenophobia among some 'local' people also contribute to this. There is a risk of the establishment of discriminatory practices in social perception, as well as its assessment as normal.

It was mentioned at the outset that Russia is not a traditional immigrant-receiving country and does not have experience in acting as a 'melting pot'; declarations of the further liberalisation of the policy on migration are met negatively; and it is restrictive means that are seen as the major tool in eliminating illegal labour migration. This mood can also be traced to the level of the St. Petersburg government: in the framework of the city programme 'Tolerance' (a programme for the harmonisation of inter-ethnic and inter-cultural relations, for the prevention of xenophobia and the promotion of tolerance),${ }^{18}$ there is a section devoted to the adaptation of labour immigrants. Only $4 \%$ of all the arrangements in this programme were devoted to migrants and their adaptation and integration; their main focus was raids and the checking of the paperwork of immigrants, which was performed mainly by the committee for the issues of law, order and security.

\section{Conclusions}

The Russian Federation is second only to the United States of America in the amount of workforce it imports; its scant experience in dealing with immigration leads to Russia facing difficulties as do other receiving countries. Migration is a controversial process: it has the potential for advantages which Russia can exploit, as well as disadvantages and risks, among which is included marginalisation. Adaptation closely associated with illegal practices is unable to prevent this risk; thus, social management seeks to create the conditions for adaptation in the direction required. This will require a monitoring of the situation: what formal and informal institutions operate in the field and the extent to which they are effective.

At the moment, it can be said that the lack of formal institutions that might be considered effective in the sense of costs leaves sufficient space for the appearance and operation of informal institutions that can be connected to illegal practices. This is connected with a special kind of adaptation from which neither society nor migrants benefit.

18 See the official website of the St. Petersburg government: http://www.gov.spb.ru/today? newsid=4661 [last accessed 15 April 2010]. 